\title{
Longleaf Uniola and Spike Uniola Require Shade
}

\section{GALE L. WOLTERS}

Highlight: Three years after establishment, longleaf uniola and spike uniola plants under $92 \%$ shade were larger, more numerous, and more vigorous than those receiving more sunlight. Herbage production was 10 times greater in $92 \%$ shade than in full sunlight. Protein, phosphorus, calcium, and ash content of the herbage increased as shade deepened, while crude fiber and N.F.E. content decreased.

Because of their ability to grow under tree canopies and to provide green herbage in winter, longleaf uniola (Uniola sessiliflora) and spike uniola (U. laxa) are important forage plants in the extensive loblolly-shorlleaf pine-hardwood forest type of the South. As a matter of observation, the two grass species grow even under the densest tree cover and are rare or absent on well-lighted sites.

In an effort to provide more specific information, a study was made to determine how artificial shade of several intensities affected establishment, growth, and chemical composition of the two grasses. Since measurements were made throughout the year, the research also provided data on seasonal aspects of the plants' growth.

\section{Procedure}

The study took place on the Palustris Experimental Forest in central Louisiana. The nearly level area had deep, mediumtextured soils with imperfect internal drainage. It was thus typical of soils where longleaf and spike uniola occur most abundantly. All woody vegetation was removed, and the old rough was burned during December, 1966, to facilitate seedbed preparation.

Sixteen 8 -by 10 -ft plots separated by $10-\mathrm{ft}$ aisles of native cover were systematically established in an exclosure. Plots were spaded and leveled initially during February, 1967, and were rotary-tilled twice in April. Forest Experiment Station, U.S. Department of Agriculture, Forest Service, Pineville, Louisiana.

Manuscript received January 12, 1973.
The author is range scientist, Southern
A composite mixture of longleaf uniola and spike uniola seed, collected in the nearby forest the previous fall, was hand-seeded on the freshly raked plots in late April. About $1 / 4$ pound (air-dry weight) of pretreated (Wolters, 1970) uncleaned seed was applied per plot. Seeds were placed in parallel rows 12 inches apart and covered with a very thin layer of tamped soil.

Shade intensities of $0,30,63$, and $92 \%$ were randomly assigned and replicated 4 times. Cloth woven to produce the prescribed shade intensity was placed $3 \mathrm{ft}$ above the soil surface.

Measurements of longleaf uniola were made periodically during 1967,1968 , and 1969 to determine number of leaves and tillers per plant, length and width of basal leaves, and height of seed stalks. Counts of longleaf and spike uniola plants $/ \mathrm{ft}^{2}$

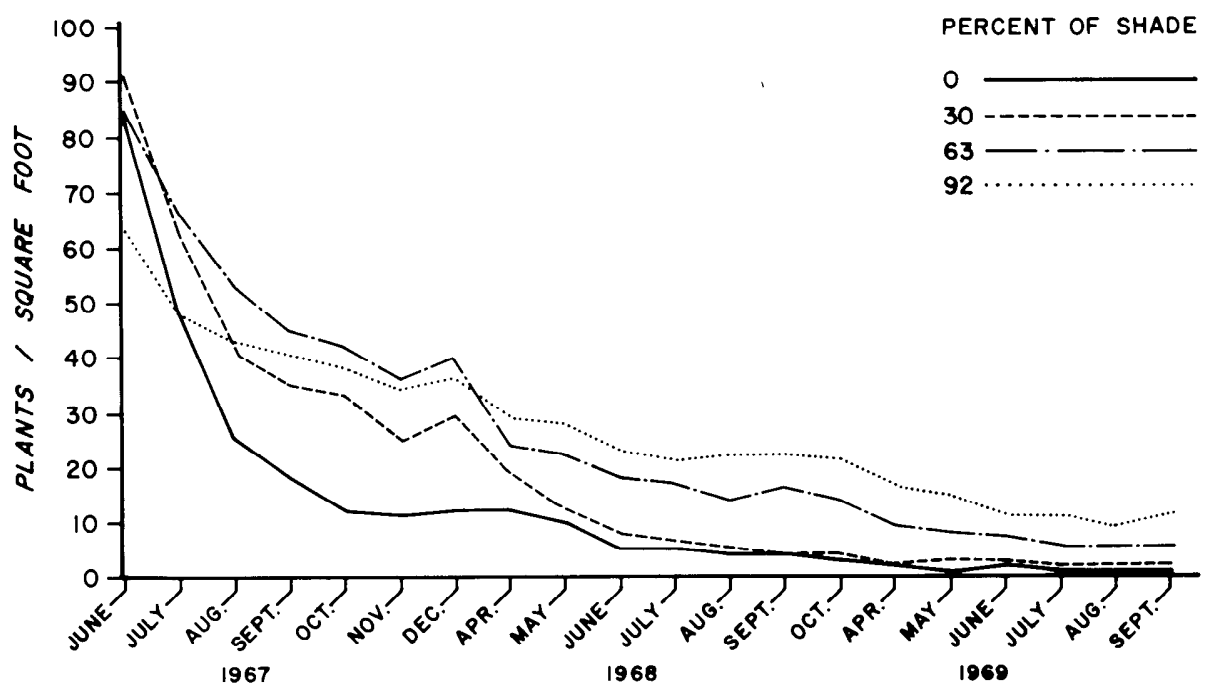

Fig. 1. Uniola plants per square foot under four levels of shade. The peaks in late 1967 were probably caused by delayed germination. mined by hand-stripping two 1.55-by 1.55 -ft quadrats on each plot. Germination was tested during the winter of included temperature and relative humid ity at 4 inches above the soil surface. All measurements were made within a 6-by 8 -ft sampling area centered on each plot.

A profuse growth of weedy forbs and grasses annually invaded the study plots. The competing vegetation was plucked by hand during September 1967, June and September 1968, and June 1969.

\section{Morphological Development}

Air temperature directly above the control plots ( $0 \%$ shade) averaged less than $2^{\circ} \mathrm{F}$ warmer than above the coolest treatment ( $92 \%$ shade). Likewise, relative humidity above the controls was less than 2 percentage points lower than above the

PERCENT OF SHADE coincided with phenological measurements. Herbage production was determined in September, 1969, by clipping four randomly located 1-by 1 -ft quadrats on each plot. Samples were oven-dried at $75^{\circ} \mathrm{C}$, weighed, and composited for chemical analysis. Seed production was deter1969-1970. Environmental measurements 
densest shade. Except for the degrce of shade, treatments apparently influenced plant microenvironment negligibly.

By the end of June, 1967, seedling density averaged 81 plants $/ \mathrm{ft}^{2}$. Most plants were in the third-leaf stage of development, and the lowermost leaf averaged about $1.8 \mathrm{~mm}$ wide. Lengths of basal leaves under 0,30 , and $63 \%$ shade were similar (13.5 $\mathrm{mm}$ average), while leaves under $92 \%$ shade were significantly longer $(20.3 \mathrm{~mm})$.

During the first year, seedling mortality ranged from about 50\% under $92 \%$ shade to $85 \%$ under full sunlight (Fig. 1). By mid-September, 1969, survival averaged 18\% under heavy shade and about $1 \%$ in full sunlight. Though mortality was high on all plots, plant density from mid-August, 1967, to the close of the study was significantly greater under 63 and $92 \%$ shade than in full sunlight (Fig. 2).

Plants in heavy shade wcre dark green and appeared more vigorous than the yellowish-green plants receiving more sunlight. Daubenmire (1955) states that when shade plants are exposed to full sunlight they may not be able to synthesize chlorophyll at a rate fast enough to replace what is lost by decomposition.

Shading also appeared to influence species establishment. Longleaf uniola made up approximately $65 \%$ of the stand in $92 \%$ shade; spike uniola comprised 60 to $68 \%$ of the stand under less shade.

Shading significantly increased the number of leaves per plant. Annually in September the average for longleaf uniola was 3.4 leaves under $92 \%$ shade and 2.0 in full sunlight (Table 1). Numbers of leaves under 30 and $63 \%$ shade were intermediate.

The period when new leaves developed at a maximum rate appeared to occur prior to June. Many were initiated during the fall and winter, grew slowly but continuously throughout the winter, and matured the following summer; such a pattern is characteristic of a cool-season plant (Huss, 1964). Yarlett (1965) also considered both longleaf and spike uniola to be cool-season growers.

During 1967 plants under 0 and 30\% shade bore the greatest number of leaves in June. Thereafter leaf density decreased with each successive inventory. Under 63 and $92 \%$ shade, number of leaves per plant increased up to mid-August to September, and then declined. Leaf density closely paralleled leaf browning and drying, which was observed first in full sunlight and then at successive later dates under increased shade. Apparently intense sunlight hastened leaf maturity.

During the first year, basal leaves continued to increase in length until late October, but during successive years maximum length was generally obtained in July or August. In September leaf length
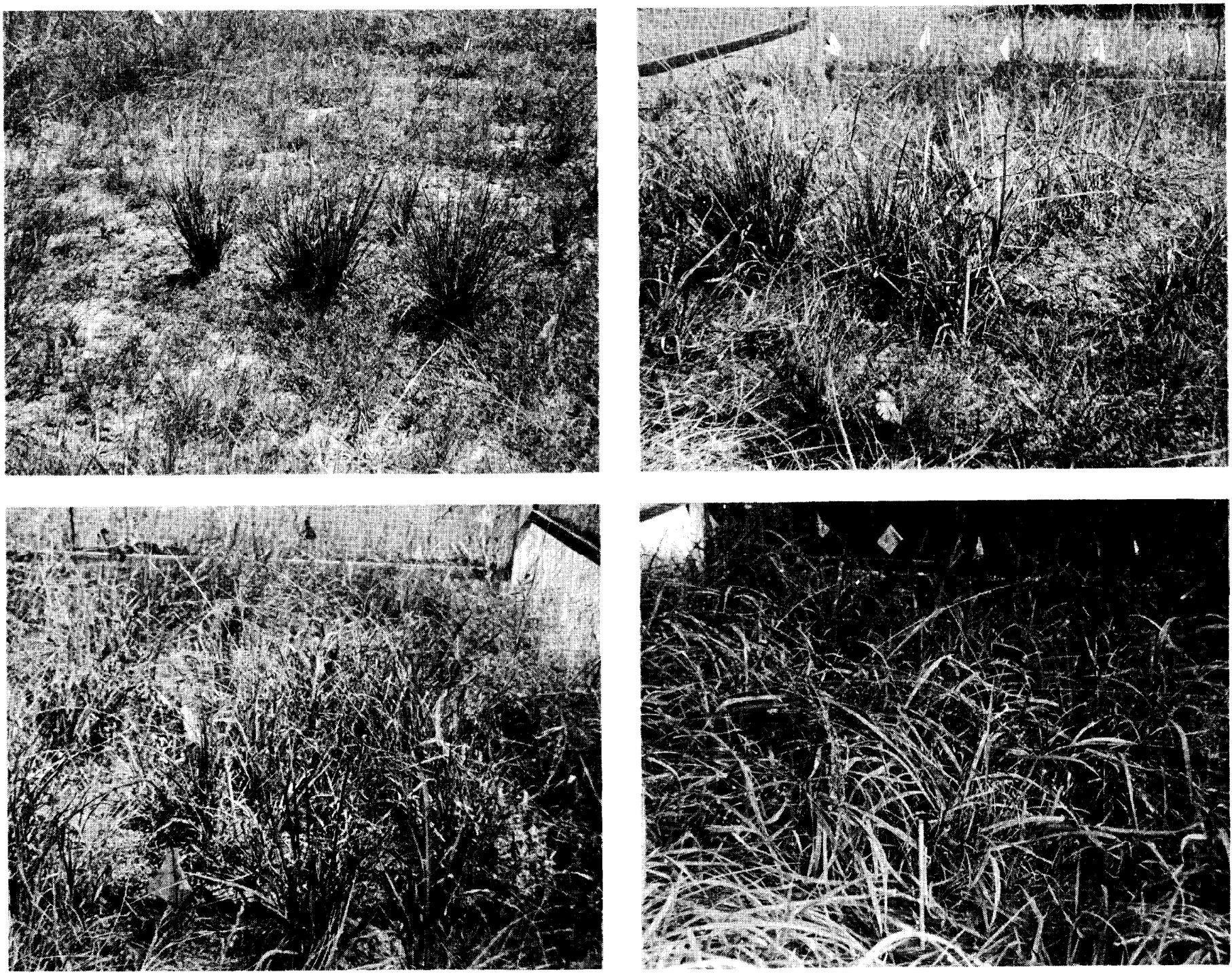

Fig. 2. Comparison of the size and abundance of uniola in full sunlight (upper left), 30\% shade (upper right), 63\% shade (lower left), and 92\% shade (lower right). Photos were made in September, 1969, by which time other grasses had invaded the plots. 
Table 1. Morphological development of longleaf uniola during September 1967, 1968, and 1969 under four levels of shade.

\begin{tabular}{|c|c|c|c|c|}
\hline \multirow[b]{2}{*}{ Date } & \multicolumn{4}{|c|}{ Percent of shade } \\
\hline & 0 & 30 & 63 & 92 \\
\hline \multicolumn{5}{|l|}{ September 28,1967} \\
\hline Plants $/ \mathrm{ft}^{2}$ & $13.0 \mathrm{~b}^{1}$ & $34.0 \mathrm{a}$ & $44.0 \mathrm{a}$ & $38.0 \mathrm{a}$ \\
\hline Leaves/plant & $1.7 \mathrm{c}$ & $2.1 \mathrm{bc}$ & $2.5 \mathrm{~b}$ & $3.2 \mathrm{a}$ \\
\hline Length of basal leaf $(\mathrm{mm})$ & $39.2 \mathrm{ab}$ & $36.3 \mathrm{~b}$ & $39.3 \mathrm{ab}$ & $54.4 \mathrm{a}$ \\
\hline Wid th of basal leaf $(\mathrm{mm})$ & $1.7 \mathrm{a}$ & $1.7 \mathrm{a}$ & $1.9 \mathrm{a}$ & $2.2 \mathrm{a}$ \\
\hline Number of tillers/plant & $0.1 \mathrm{a}$ & $0.1 \mathrm{a}$ & $0.3 \mathrm{a}$ & $0.7 \mathrm{a}$ \\
\hline \multicolumn{5}{|l|}{ September 23,1968} \\
\hline Plants $/ \mathrm{ft}^{2}$ & $3.0 \mathrm{c}$ & $4.0 \mathrm{c}$ & $14.0 \mathrm{~b}$ & $22.0 \mathrm{a}$ \\
\hline Leaves/plant & $2.5 \mathrm{~b}$ & $3.0 \mathrm{~b}$ & $3.2 \mathrm{ab}$ & $3.8 \mathrm{a}$ \\
\hline Length of basal leaf (mm) & $42.5 \mathrm{~b}$ & $56.7 \mathrm{~b}$ & $67.9 \mathrm{~b}$ & $121.9 \mathrm{a}$ \\
\hline Wid th of basal leaf $(\mathrm{mm})$ & $2.2 \mathrm{~b}$ & $2.5 \mathrm{~b}$ & $2.6 \mathrm{~b}$ & $3.6 \mathrm{a}$ \\
\hline Number of tillers/plant & $1.1 \mathrm{~b}$ & $1.8 \mathrm{~b}$ & $3.2 \mathrm{a}$ & $3.4 \mathrm{a}$ \\
\hline Seed stalks $/ \mathrm{ft}^{2}$ & $0.0 \mathrm{a}$ & $0.1 \mathrm{a}$ & $0.8 \mathrm{a}$ & $1.2 \mathrm{a}$ \\
\hline Leng th of seedstalks $(\mathrm{mm})$ & $0.0 \mathrm{a}$ & $211.0 \mathrm{a}$ & $260.0 \mathrm{a}$ & $620.0 \mathrm{a}$ \\
\hline \multicolumn{5}{|l|}{ September 18,1969} \\
\hline Plants $/ \mathrm{ft}^{2}$ & $1.0 \mathrm{c}$ & $2.0 \mathrm{c}$ & $5.0 \mathrm{~b}$ & $11.0 \mathrm{a}$ \\
\hline Leaves/plant & $1.8 \mathrm{a}$ & $2.9 \mathrm{a}$ & $2.8 \mathrm{a}$ & $3.2 \mathrm{a}$ \\
\hline Length of basal leaf (mm) & $55.5 \mathrm{c}$ & $97.0 \mathrm{~b}$ & $102.2 \mathrm{~b}$ & $137.4 \mathrm{a}$ \\
\hline Width of basal leaf (mm) & $2.0 \mathrm{c}$ & $3.5 \mathrm{bc}$ & $4.7 \mathrm{ab}$ & $5.6 \mathrm{a}$ \\
\hline Number of tillers/plant & $4.3 \mathrm{~b}$ & $8.3 \mathrm{~b}$ & $13.2 \mathrm{a}$ & $6.9 \mathrm{~b}$ \\
\hline Seed stalks $/ \mathrm{ft}^{2}$ & $1.1 \mathrm{c}$ & $4.0 \mathrm{bc}$ & $8.0 \mathrm{ab}$ & $9.8 \mathrm{a}$ \\
\hline Length of seedstalks (mm) & $153.0 \mathrm{a}$ & $372.0 \mathrm{a}$ & $483.0 \mathrm{a}$ & $569.0 \mathrm{a}$ \\
\hline Seed yield (lb/acre) & $0.0 \mathrm{a}$ & $0.0 \mathrm{a}$ & $123.0 \mathrm{a}$ & $230.0 \mathrm{a}$ \\
\hline Herbage yield (lb/acre) & $173.0 \mathrm{c}$ & $759.0 \mathrm{bc}$ & $1,319.0 \mathrm{ab}$ & $1,839.0 \mathrm{a}$ \\
\hline
\end{tabular}
${ }^{1}$ If followed by a common letter, treatment means in the same row are not significantly different
at the 0.05 level.

averaged $46,63,70$, and $105 \mathrm{~mm}$ for plants grown in $0,30,63$, and $92 \%$ shade. Basal leaves of new tillers generally initiated growth in August. Since they were averaged in with the mature ones, the effect was to decrease length in fall.

The period of leaf width growth coincided with that of length growth. Except in 1967 , basal leaves were 50 to $90 \%$ wider under $92 \%$ shade than in full sunlight, with the average annual leaf width ranging from 3.4 to $2.0 \mathrm{~mm}$, respectively. Basal leaf growth in $63 \%$ shade was intermediate.

In 1967 tillering was initially observed in mid-August. By November tillers were present on about $1 / 4$ of the plants in 0 and $30 \%$ shade and on nearly all plants in $92 \%$ shade. Tillering occurred during every month of the year but was most apparent during the fall. Treatments did not appear to influence the number of tillers per plant, but the sampling procedure may have masked differences. During the first growing season, tillers were easily distinguished from seedlings; during successive years adjacent plants intermingled and counting was very difficult.

Initiation of seedstalks was observed as early as June 1 and as late as October during a mild fall. Usually, growth had begun by the first of July. Flowering likewise varied but was generally at its peak during late August and September. Some flowers were observed as late as mid-November, but most seeds were mature by mid-October.

No seedstalks appeared in 1967 and only a few in 1968. In 1969, however, seedstalk numbers increased significantly with degree of shading. Neither seedstalk length (which was highly variable), seed production, nor germination rate (average $52 \%$ ) was significantly affected by the level of shade.

\section{Herbage Production and Analyses}

Herbage production was $173 \mathrm{lb} /$ acre in full light, $759 \mathrm{lb}$ in $30 \%$ shade, 1,319 lb in $63 \%$ shade, and $1,839 \mathrm{lb}$ in $92 \%$ shade. The differences were significant. McDonough (1969) and Harshbarger and Perkins (1971), working with eastern grasses and partridgepea, reported increased growth with up to $55 \%$ shade. I eithead et al. (1971) stated that longleaf uniola is best adapted to areas that are shaded more than $50 \%$ at midday.

Protein, phosphorus, calcium, and ash in longlcaf and spike uniola herbage

Table 2. Chemical analysis (\%) of longleaf and spike uniola herbage collected during September 1969.

\begin{tabular}{lcccc}
\hline \multirow{2}{*}{$\begin{array}{l}\text { Chemical } \\
\text { component }\end{array}$} & \multicolumn{4}{c}{ Percent shade } \\
\cline { 2 - 5 } Protein & 5 & 30 & 63 & 92 \\
Fat & 2.4 & 6.6 & 7.4 & 9.3 \\
Fiber & 33.0 & 34.2 & 34.8 & 2.3 \\
Ash & 9.9 & 9.3 & 10.2 & 15.6 \\
Calcium & .19 & .21 & .20 & .27 \\
Phosphorus & .03 & 04 & .05 & .07 \\
N.F.E. & 49.0 & 47.5 & 45.1 & 41.9 \\
\hline
\end{tabular}

increased with shade intensity (Table 2). Under 92\% shade, protein was more than $50 \%$ higher and phosphorus content was more than double that in full sunlight. Content of crude fiber and nitrogen-free extract declined with increased shade intensity. Fat (ether extract) content was unaffected. Burton et al. (1959) reported similar responses of protein and phosphorus to shading in coastal bermudagrass; they also found that cellulose and lignin increased, but total available carbohydrates decreased with shading.

\section{Conclusions}

On the basis of present data and supporting literature, longleaf and spike uniola should be classed not merely as shade-tolerant but as shade-dependent. Maximum growth and production were obtained with $92 \%$ shade, while in full sunlight survival and growth were poor.

Growth patterns typify uniolas as cool-season plants that produce beneficial winter herbage for cattle and wildlife.

It appears that both amount of forage and nutritive values can be varied by manipulation of overstory density. Where trees provide the shade, however, they also compete for moisture and nutrients. Such effects probably must be allowed for if attempts are made to apply the present findings to forest grazing land conditions.

\section{Literature Cited}

Burton, G. W., J. E. Jackson, and F. E. Knox. 1959. The influence of light reduction upon the production, persistence and chemical composition of coastal bermudagrass, Cynodon dactylon. Agron. J. 51:537-542.

Daubenmire, R. F. 1959. Plants and environment. 2nd. ed. John Wiley and Sons, Inc. N. Y. 422 p.

Harshbarger, T. J., and C. J. Perkins. 1971 Effect of shade on growth and seed production of partridge-pea. J. Wildlife Manage. 35:382-385

Huss, D. L. (Chairman, Range Term Glossary Committee). 1964. A glossary of terms used in range management. Amer. Soc. Range Manage. 32 p., Portland, Ore.

Leithead, H. L., L. L. Yarlett, and T. N. Shiflet 1971. 100 native forage grasses in 11 southern states. U. S. Dep. Agr. Handb. 389 $216 \mathrm{p}$.

McDonough, W. T. 1969. Use of saran shade cloth in greenhouse to improve summe seedling growth of five mountain range grasses and forbs. U. S. Dep. Agr., Forest Serv. Res. Note INT-99. 6 p. Intermountain Forest and Range Exp. Sta., Odgen Utah.

Wolters, G. L. 1970. Breaking dormancy of longleaf uniola seeds. J. Range Manage. 23:178-180.

Yarlett, L. L. 1965. Important native grasses for range conservation in Florida. U. S. Dep. Agr., Soil Conserv. Serv. 163 p. 